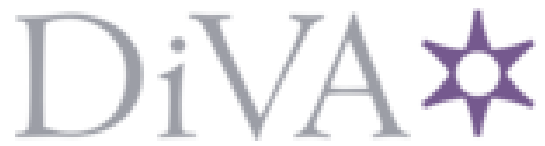

http://www.diva-portal.org

Preprint

This is the submitted version of a paper published in Journal of Population Ageing.

Citation for the original published paper (version of record):

Lundgren, A S., Ljuslinder, K. (2011)

Problematic demography: representations of population ageing in the Swedish daily press

Journal of Population Ageing, 4(3): 165-183

https://doi.org/10.1007/s12062-011-9048-2

Access to the published version may require subscription.

N.B. When citing this work, cite the original published paper.

Permanent link to this version:

http://urn.kb.se/resolve?urn=urn:nbn:se:umu:diva-47629 


\title{
Problematic demography. Representations of population ageing in the Swedish daily press
}

\author{
Anna Sofia Lundgren and Karin Ljuslinder ${ }^{1}$
}

\begin{abstract}
The ageing of populations has been a topic of discussion during the last few decades, but how is this subject represented in the media, and what images of old age are produced? In this article we present the results of a quantitative content analysis that investigates how the concept of population ageing has been represented in Swedish local and national daily news press between 1988 and 2009, and the old age positions that are offered in these representations. We also use discourse analysis in order to qualitatively examine the ways in which the concept of population ageing is articulated in these news press articles and the old age positions that are thereby constituted. The results show that the concept is constituted as a naturalised expert concept, and is primarily used in order to contextualise articles about future political and economical difficulties or even crises. By articulating population ageing with both political policies, political economy and older people's (as a group) reported need for care and services, population ageing was constituted as a political economic concern rather than a problem for the aged individual.
\end{abstract}

Key words: population ageing, identity, media, representations

\section{Introduction}

The mass media is considered to be society's most far reaching and pervasive source of information. Therefore, the mass media has often been described as society's greatest (re)producer of cultural images and values, especially regarding phenomena and processes that lie beyond our direct personal reach. For the vast majority of people, the mass media is one of the most important sources of information and knowledge in the afore-mentioned areas. Marshall Mc Luhan's (1967) description of the mass media as our prolonged senses is classical in this sense. In this article we focus on how the concept of population ageing has been represented by the Swedish news press and thus made available to a wider public. We are also specifically interested in how images of older people are constituted within these reports. ${ }^{2}$

When used within a scientific, primarily demographic discourse, the concept of population ageing is an indicator of a rise in the median age of the populations that is most often associated with two parallel processes; a declining fertility rate and an increasing longevity rate (cf. Harper \& Leeson 2008. See also Bengtsson 2010). The supposed "reality" behind the concept as it is used within this discourse is often supported - and thus constituted - by statistics and graphs that show how the proportion of older people is growing rapidly. This scenario is represented in the developed countries and developing and transitional countries, and leads to a change in the so-called population pyramid.

Demographically, Sweden has undergone a process of population ageing since the industrialization in the late $19^{\text {th }}$ and early $20^{\text {th }}$ centuries (Bengtsson 2010). The

\footnotetext{
${ }^{1}$ A. S. Lundgren, Centre for Population Studies/Ageing and Living Conditions Programme (ALC) and Department of Culture and Media Studies, Umeå University, 90187 Umeå, Sweden.e-mail: annasofia.lundgren@kultmed.umu.se

K. Ljuslinder, Department of Culture and Media Studies, Umeå University, 90187 Umeå, Sweden.

${ }^{2}$ We are aware that this focus partly enhances the tendency to focus on the calculated increase of older persons instead of other contributing causes and parallel processes, as for example the decrease in younger persons and the tendency that people tend to wait longer to have their first child. The studied material also contains representations of other age categories. Examining these would be interesting, but falls outside the scope of this investigation.
} 
Swedish official report Äldrepolitik för framtiden (Eng.: Old age policy for the future) (SOU 2003:91, p. 73) describes an ongoing transition from a predominance of children and adolescents to an increased proportion of middle-aged and older people. According to the report, during the last stage of this transition the major increase will be in the oldest age groups. The report further predicts that large parts of the world will experience the hitherto unknown effects of an ageing population by the year 2050, something that the report suggests can already be seen in some areas such as the sparsely populated inland of Northern Sweden. Similar observations have also been made elsewhere. For example, studies have shown that older adults are overrepresented in rural areas and that the older proportion of the population is growing faster in rural areas than in urban areas (Keating \& Phillips, 2008; Hilt \& Lipschultz 2005).

As a nation state, Sweden is of special interest in the discussion of the consequences of population ageing because of its welfare system, which is primarily funded by income taxes (Bengtsson 2010). ${ }^{3}$ During almost the entire $2 \mathrm{O}^{\text {th }}$ century, Sweden had a social democratic government, aiming at a universal welfare administered by a large public sector and available to rich and poor alike by transferring the income taxes without means tests (Magnusson 2006). Since 2006, Sweden has a liberal coalition government, which has led to a liberalization of the welfare system, and there is a discussion about the degree of dismantling that the Swedish model has undergone (Bergh 2010).

When it comes to representations of population issues in the Swedish press, Abramsson (2005) has concluded that between 1994 and 2004 there was a change in the reports on population issues. According to Abramsson, this change has involved a change from reporting almost exclusively about population movements to including reports on changes in the population structure. Abramsson does not specifically focus on how old age per se is represented in her material. However, she mentions the baby boomers as a category that is explicitly referred to as a rather well off category whose members make high demands on service, accommodation and care. Similar results have led other researchers to comment on how portrayals of older people have become more varied since the 1980 os (Vickers 2007), possibly as a response to population ageing; this is ascribed to the economic and political power of the now retiring age group (cf. Dail 1988; Center for Health Communication 2004. See also Nilsson 2008, p. 18; Walker \& Naegle 1999).

Studies on population ageing from a cultural or social science perspective have shown how the concept is mostly referred to as a societal threat, and the representations are sometimes spoken of in terms of "apocalyptic demography" (Vincent 1996; Robertson 1997; Gee \& Gutman 2000; Rozanova 2006). They are said to focus on economic costs and population ageing as a threat. Mullan (2002) argues that the fearful notions of population ageing are imaginary, or at least highly exaggerated. Media representations of population ageing have been discussed by a few scholars. Northcott (1994, p. 68) claims that the media in general has "tended to fuel" a notion of population ageing as the primary cause of Western economic crisis. According to McDaniel (1987), media representations on population ageing as an economic problem tend to fulfill themselves because of the so-called "bandwagon effect" (see also Northcott 1994); whether or not correct in the first place, what is represented as true in the media tend to be perceived and treated as true. According to this research, the apocalyptic view on population ageing has been widely used as

\footnotetext{
${ }^{3}$ This is sometimes referred to in terms of "the Swedish model", or "Nordic model" because the other Nordic countries have similar welfare systems.
} 
an explanation of political-economic problems and decreased growth, experienced by many Western countries.

We have not found any studies that examine how the concept population ageing has itself been represented in media. Neither have we found any studies that have investigated images of old age in media reports on population ageing. ${ }^{4}$ However, a great deal of research has been carried out on how different media have represented older people in general (Healy \& Ross 2002). Such studies offer valuable information for understanding the cultural imaginaries of older people that the news press representations of population ageing relate to. They are also important in order to compare how the old age images offered by the news press reports on population ageing resemble or differ from the more general old age representations.

Research has frequently pointed out that the media in general generates ambiguous pictures of ageing. For example, it is said that older people are either portrayed as weak and in need of care or as active and still-going strong (Cole 1992; Featherstone 1995; Dozois 2005; Blaakilde, Kirk \& Swane 1998; Andersson 2008; Nilsson 2008). Some studies have found that older people are mainly portrayed as employed, healthy, and socially and physically active characters who enjoy high social prestige (cf. Kessler, Rakoczy \& Staudinger 2004), while others state that the media portray older people by repeatedly pointing out negative traits such as illness as one of the principal characteristics (Cohen 2002; Rozanova 2006).

Crucial for how old age is represented is the specific media channel and/or genre they appear in. Some scholars argue that older people receive a more "adequate" and multifaceted coverage in daily press news than in other media channels and genres (Robinson et al 2003). Others have shown that the news press focuses on the cost of unhealthy ageing, thus bypassing broader socio-economic explanations (Rozanova 2006; Chappell et al 2003). An investigation of images of old age in the Danish press found that older people were generally presented as strong, but in the specific realm of the news genre there was a dominant image of older people as weak. Contrary to the results of Vickers (2007), the Danish results suggested that this image has increased since the 1980s (Elmelund-Præstekær \& Wien 2006), a suggestion that seems to correspond fairly well with Swedish results (cf. Andersson Odén 2003, 2005; Magnusson 2008). Nilsson (2008) has described how "negatively" charged aspects of old age in general, specifically in relation to competence and autonomy, are the ones that dominate in the Swedish news press.

\section{Aim}

Even though population ageing is a concept that is fairly common within a demographic discourse, most people that are not part of this discourse encounter the concept primarily through media reports. They are thereby confronted with the cultural meanings that are attached to the concept within media discourses and with the old age positions that are offered by those discourses. It is known that people partly build their identities from the values that are repeatedly represented in the media, and draw on existing stereotypes in building their age identities (Lin et al 2004). The impact of the media on individuals' self-perceptions as well as on society's resource allocation (Ljuslinder 2002) emphasises the importance of not only describing these media images, but also of understanding how a discourse on a

\footnotetext{
${ }^{4}$ It has been suggested, however, that as a consequence of a future that involves population ageing conflicts between generations will be portrayed as complex and difficult to solve (Cohen, Adoni \& Bantz 1990), and that the mass media are likely to start distributing stories and myths on the baby boomers (Hilt \& Lipschultz 2005).
} 
phenomenon like population ageing seems to offer certain (old age) positions, and not others, once it is conceptualised and mediated by the media.

The aim of this article is to examine how the concept of population ageing has been represented in the local and the national Swedish daily press from 1988 to 2009. The time period is chosen in order to cover the increased media awareness of population ageing that occurred in the late 1990s (cf. Abramsson 2005). Which instances of population ageing discourse are present and prevail, and what notions of old age and older people that are present in the media reports on population ageing? The article also aims to investigate the specific articulations of population ageing that are made in the printed news about areas in Sweden where there is a specifically aged population, and where age has been described in terms of difficulty due to, for example, cutbacks in services, long distances and out-migration (Eriksson 2010).

\section{Material, methods and theoretical points of departure}

Three Swedish daily newspapers were selected, Dagens Nyheter (Eng.: The Daily News), Västerbottens-Kuriren (Eng.: Västerbotten's Courier) and Aftonbladet (Eng.: The Evening Sheet). Dagens Nyheter is the largest Swedish morning newspaper and is distributed to subscribers across the whole country. Västerbottens-Kuriren is a local newspaper and is published in Umeå. Besides national and international news it covers regional news from the county of Västerbotten in northern Sweden. The stated position of both newspapers' editorial pages is "liberal" although Dagens Nyheter uses the phrase "independently liberal". Dagens Nyheter and Västerbottens-Kuriren have a large amount of subscribers. The third newspaper, Aftonbladet, is Sweden's largest boulevard-press, and its stated position is independently social democrat.

Dagens Nyheter and Aftonbladet were chosen because of their sizes and their national coverage. The local newspaper Västerbottens-Kuriren was chosen because it covers an area in Sweden that has a particularly aged population in terms of average age. While the average age is 39,1 in Stockholm and 38,1 in Umeå, the largest town in Västerbotten, some municipalities in the inland of Västerbotten in Norrland have an average age that is as high as 47,3 (Åsele) and 47,9 (Dorotea) (www.scb.se, 2009). Because of out-migration, the inland of Norrland has already been confronted with some of the problems associated with an ageing population. This experience of the process of population ageing makes it interesting for us to examine the specific articulations of the concept that are made in this local media.

In what follows we will describe the results of the quantitative content analysis of the chosen Swedish local and national daily newspapers and pursue a qualitative analysis of the quantitative results based on discourse theory. However, before this we will explain how the material was chosen, gathered and coded.

Articles containing the expression "population ageing" were collected by searching the full-text online databases Mediearkivet (for Västerbottens-Kuriren) and Presstext (for Dagens Nyheter and Aftonbladet), during the period 1988-2009. The search words used were "age* population*" and "population* age*". This search yielded 454 articles. In order to capture alternative semantic formulations of the concept, we also performed searches in articles that contained both "age*" and "population*" respectively (age* AND population*); for example in formulations like "the ageing of the population" and "populations are ageing". Articles that contained both words, but that were either duplicates of already found articles, or did not at all deal with questions that had to do with population ageing in any of the found 
definitions, were removed by the authors. 5 This search yielded an additional of 140 articles. In total 594 articles were found, which was considered sufficient to see trends in the representations.

The articles were coded for the general variables genre and main topic to obtain an overview of the material, and for the research questions of the project. We hence coded for definitions of population ageing, expected consequences of population ageing, old age positions, what positions that were referenced or used as source, whether population ageing was presented as a demographic fact, and whether the article related specifically to the local context of Västerbotten's inland. Frequencies of certain genres, main topics and so on, helped to highlight the cultural construction of meaning that was made within the studied representations.

The code scheme did not use predetermined variable values as its starting point, but let the values discern inductively through a pilot study, which was carried out initially on a small random sample of the material (50 articles) (cf. DowneWamboldt 1992). Through the pilot study variable values were discovered which were then included in the code scheme; for example, "taxing", "care-dependent" and "pensioner" were included amongst other descriptions as variable values of the variable "old age positions". The pilot study was also used to carry out an interreliability test in order to secure that the raters had an agreement on how to code the articles in the code scheme. We, the authors, coded the material ourselves, as we wanted to get to know the material on a deeper level than just frequencies. After having coded the first 50 articles in the pilot study separately, we discussed the results and made sure we agreed well on how to code the material. We also discussed whether also to include more variables than the ones raised by the research questions, which we finally decided was not needed. During the coding of the total amount of articles, we worked closely together, asking each other for advice when encountering uncertainties.

After coding the material, we carried out a classical quantitative content analysis (cf. Berelson 1952). The great advantage of quantitative content analysis is that it systematizes large data-material. The result gave an overview of the content, which then served as a platform for qualitative discourse analysis, which we describe below.

In the gathered material we also noted alternative descriptions of the phenomenon of population ageing and performed additional searches using these alternative words and phrases. We hereby came to collect articles that used phrases like "demographic challenge", "the retiring of the baby-boomers", "age shock", "age bomb", "age-explosion" and "age boom". As our aim was to examine representations of the concept of population ageing, these alternative descriptions were not included in the main material, but used to show a tendency towards what might, following Fairclough (1995) and Winther Jørgensen \& Phillips (2002), be called the discursive order; that is, alternative discourses that try to make the phenomenon of an ageing population comprehensible without using the specific concept. These articles $(n=101)$ were analysed separately in order to ensure a comparative material, and to contrast the findings from the main material.

The analytical concepts through which we scrutinised the material qualitatively were taken from discourse theory as it has been developed by Laclau and Mouffe (1985). "Discourse" is thus understood as a specific way of understanding and talking about something, and seen as constitutive of reality as we know it. It is

\footnotetext{
${ }^{5}$ One example of an article that was removed was an article about a fishing lake in Cambodia (Aftonbladet 091008). The article contained the sought-after word age* in the following sentence: "The fishermen are of all ages". The sought-after word population* was found in a sentence describing how the lake provided all the fish that "the country's population consumes". But the article did not describe anything that had to do with any ageing of the population.
} 
implicit that there is always the possibility of talking about and understanding things in a different way.

Different discourses create meaning by ordering signs in different ways. This ordering practice will be referred to as "articulation". For example, a discourse on old age as decline would perhaps articulate the sign "old age" with signs as "loss of position", "weakness" and "illness", whereas a discourse on old age as liberation would perhaps articulate "old age" with "retirement", "free time" and "rest". What is central to the concept of articulation is that it refers to any practice that creates a relation between signs, and that the previous meanings of the respective signs that are articulated are changed through the articulatory practice (Laclau \& Mouffe 1985). Articulation is thus a question of signification. We will use the concept to point at different assertions of particular orders; that is, moments where the sign "population ageing" is articulated with different signs and thus made to constitute meaning.

"Representation" is a word that refers to specific articulations that are on display; for example, media articles on a specific theme. Representation is sometimes used quite synonymously with the concept of articulation. Similarly to articulation, it has often been described how every effort to represent something; that is, every effort to present something that is not present, always introduces something new to the representation (Laclau \& Mouffe 1985; Hall 1997). Consequently, even the most sincere effort to describe a phenomenon neutrally affects, and recreates, this very phenomenon because it is described from a particular perspective, making certain selections, using certain words and relating it to certain contexts but not others. This view on representation holds for all attempts at describing things. However, in comparison with other representations, the ones made by the media have a wider scope and are also ascribed immense impact. Media representations are thus seen as culturally productive; they do not just describe phenomena ("population ageing", "old age" and so on), but also constitute them by repeating certain perspectives, angles, notions and values.

In order to highlight instances when articulations seem to be made from the assumption that resulting meanings are so widely held that they need not be expressed or explained, we use the concept "exnomination". The concept indicates the degree to which culturally constructed - and thus contingent - meaning is manifested by the sender as being obvious, self-evident and natural. The things that are mentioned (nominated) in a particular text are things that diverge from the exnominated and underlying meaning (Fiske 1991).

A further central aspect of discourse theory is the notion of the character of signs. One way of beginning an explanation of the character of signs is to recognise that no signs are ever given and totally unambiguous. A sign can, for example, be equivocal and attached to different signifieds depending on the context. A sign can also be ambiguous due to an overdetermination of signifieds (Laclau 1996). We will use the concept of "floating signifier" to point at this specific quality. When we state that "population ageing" is a floating signifier, we do so in order to shed light on how different articulations ascribe different meanings to the same concept, thus participating in a struggle to determine the meaning of the sign. 


\section{Analysis}

\section{An expert concept}

The majority of the 594 articles (76\%) belonged to the genres of "news", "debate" and "editorial".

Table 1: Genres in which the concept of "population ageing" occurred (\%)

\begin{tabular}{|l|l|l|l|l|}
\hline & $\begin{array}{l}\text { Dagens } \\
\text { Nyheter } \\
\mathbf{n = 3 9 8}\end{array}$ & $\begin{array}{l}\text { Västerbottens- } \\
\text { Kuriren } \\
\mathbf{n = 1 1 3}\end{array}$ & $\begin{array}{l}\text { Aftonbladet } \\
\mathbf{n = 8 3}\end{array}$ & $\begin{array}{l}\text { Total } \\
\mathbf{n}=\mathbf{5 9 4}\end{array}$ \\
\hline News & 31 & 33 & 25 & 30 \\
\hline $\begin{array}{l}\text { Debate/Letter } \\
\text { to the editor }\end{array}$ & 24 & 29 & 36 & 27 \\
\hline Editorial & 18 & 25 & 17 & 19 \\
\hline $\begin{array}{l}\text { Political } \\
\text { chronical/ } \\
\text { Analysis }\end{array}$ & 17 & 1 & 11 & 14 \\
\hline Reportage & 5 & & 2 & 5 \\
\hline Culture & 3 & 4 & 7 & 3 \\
\hline Other & 2 & 2 & $\mathbf{2}$ & $\mathbf{2}$ \\
\hline Total & 100 & 6 & 100 & 100 \\
\hline
\end{tabular}

When coding the material, the following definitions of the variable values were used:

News: Text about current event/s written by journalist. Includes news-items.

Editorial: Commenting text on editorial page written by the chief or political editor. The editorial often expresses the political view of the newspaper.

Culture: Text published in the culture section often written by cultural writer or journalist.

Debate/Letter to the editor: Non-editorial genre comprising texts written by politicians, experts, or private persons.

Reportage: Text with form of an in-depth story written somewhat closer to literature.

Political chronicle/Analysis: Personal text written by journalist. Offers a greater freedom to express own opinions than news articles.

Almost half (46\%) of the articles were either debate articles or editorials. This means that the concept of population ageing occurred primarily in non-editorial genres. Unlike the news genre where the writer's personal voice is almost always absent from the text, these are genres in which the voice and views of the writer are prominent. The debate articles, which constituted $27 \%$ of the total amount, were mostly written by politicians and people holding expert positions. Experts (above all researchers and politicians) were also the category that dominated among those that were referred to as sources by way of direct quotations (36\%).

One effect of the high percentage of speaking space held by politicians and experts was that population ageing came forth as a phenomenon that only experts had knowledge of - it was constituted as a field of expertise. The fact that almost no non-experts were used as sources or used the concept in debate articles or letters to the editor also contributed to population ageing being constituted as a complex of problems that primarily had implications on a social rather than an individual level.

\section{A naturalised concept}

In approximately $73 \%$ of the total material $(n=594)$ the concept of population ageing was not explicitly defined at all (Table 2). In $14 \%$ of the material, population ageing was, contrary to the established demographic definitions, not described in terms of a rise in the median age due to changes (in plural) in the population structure, but 
solely in terms of one aspect; for example an increased life expectancy (8\%), an increased number of older people in the population (5\%), or other definitions (1\%). The phenomenon was described as a demographic fact and supported by references to statistics in only $17 \%$ of the cases.

Table 2: Definitions of population ageing in the articles (\%)

\begin{tabular}{|l|l|l|l|l|}
\hline & $\begin{array}{l}\text { Dagens } \\
\text { Nyheter }\end{array}$ & $\begin{array}{l}\text { Västerbottens- } \\
\text { Kuriren }\end{array}$ & Aftonbladet & Total \\
\hline $\begin{array}{l}\text { No } \\
\text { definition }\end{array}$ & 77 & 79 & 48 & 73 \\
\hline $\begin{array}{l}\text { Increased } \\
\text { proportion } \\
\text { of older } \\
\text { people in } \\
\text { the } \\
\text { population }\end{array}$ & 13 & 11 & 17 & 13 \\
\hline $\begin{array}{l}\text { Increased } \\
\text { life } \\
\text { expectancy }\end{array}$ & 5 & 4 & 27 & 8 \\
\hline $\begin{array}{l}\text { Increased } \\
\text { number of } \\
\text { older } \\
\text { people in } \\
\text { the } \\
\text { population }\end{array}$ & 5 & 3 & 8 & 5 \\
\hline Other & 0 & 3 & 0 & \\
\hline
\end{tabular}

Furthermore, as high a proportion as $89 \%$ of the total amount of articles failed to describe any reasons behind population ageing, and $27 \%$ of the articles did not mention any expected consequences at all. When consequences were mentioned they were often stated without explanations as if they were incontrovertible and unquestionable. For example, an editorial in Dagens Nyheter begins with the following words when describing the economic situation in Sweden:

With an ageing population fewer and fewer will have to feed more and more. That is the demographic reality. (DN 020607)

Having stated this as the point of departure nothing more is said about what conditions that make this causal relation comprehensible. Population ageing is articulated with an expected increase in workload as "fewer and fewer will have to feed more and more", and this fact is fixated as "demographic reality", which does not leave any openings for alternative interpretations.

The fact that the consequences of population ageing were seldom explicitly defined did not necessarily mean that it was impossible to detect what was implicitly referred to. However, on a manifest level the concept of population ageing was decontextualised, and its meanings were exnominated, thus making implied causalities seem self evident and natural.

Had we not had immigration, Sweden would have a decrease in population. For a sparsely populated country with an ageing population, a decrease in population means impaired welfare. (Dagens Nyheter 000722)

Even if the quote above does not explicitly describe how or why population ageing may lead to a decrease in population and how or why this may have consequences for the welfare, the mentioning of immigrants and welfare implies that Sweden needs more people to retain its welfare system. Regardless of what population ageing came to mean in every single article, the amount of articles that used the concept without 
defining it, and without making explicit the suggested causal relations between population ageing and its described consequences, contributed to its naturalisation.

\section{Ageing population as threat}

A majority of the studied articles had one thing in common. They treated population ageing as a threat and a future problem in the making.

SNS [Centre for Business and Policy Studies] warns everyone that an ageing population risks driving down growth to the 1970s' levels during the coming decades. Then both the sustainability of public finances and the welfare system will be threatened. (Dagens Nyheter 040304)

This temporal positioning of the supposed problems of population ageing supported the indistinctness that the lack of definitions led to; population ageing appeared to be something catastrophic and out of control. It is a "galloping age crisis" waiting to happen writes Västerbottens-Kuriren (070713). Dagens Nyheter describes it in terms of "a ticking time bomb" (061124) and reports: "In the long run it means economic disaster" (070416).

Looking at how the articles described the consequences of population ageing, "no consequences mentioned" was the most common finding. However, this was closely followed by "threatened welfare", "increased health care needs" and "labour shortages" (Table 3) (cf. Abramsson 2005).

Table 3: Consequences of population ageing (\%)

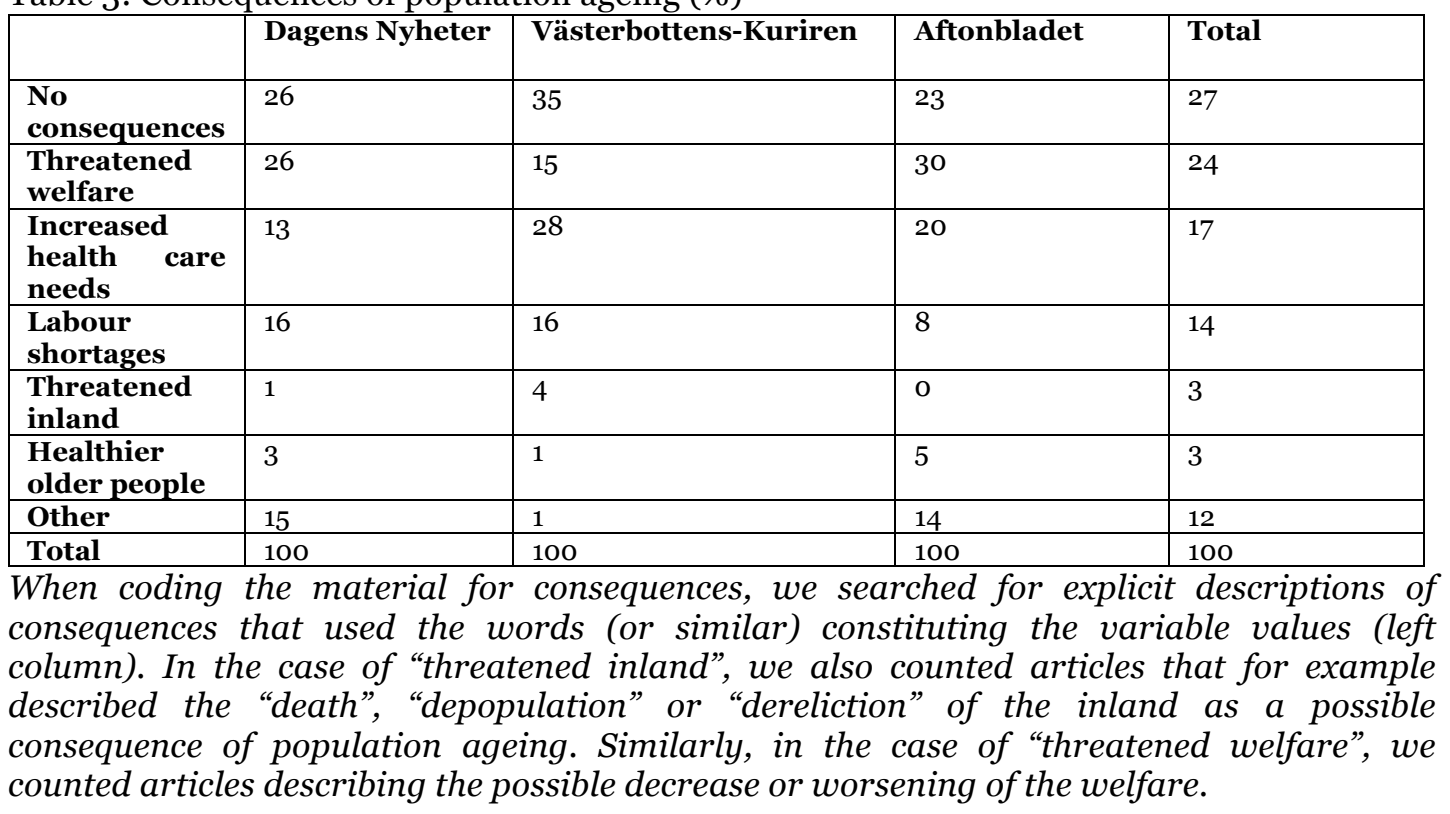

Even in articles that did not explicitly describe any consequences of population ageing, it was sometimes possible to detect underlying assumptions of threat on the basis of the way the articles dealt with solutions. Stating that we are confronted with an ageing population could for example lead to a strong argumentation in favour of increased labour immigration. It thus seemed obvious that labour shortages were seen as an expected consequence and that these were perceived as threatening and in need of a solution. 
The number one consequence that was made explicit was "threatened welfare", sometimes explicated as threatened Swedish welfare or a threatened "people's home of Sweden". "Threatened welfare" was closely followed by "increased health needs" and "labour shortages". The underlying logic of all the arguments that regarded the consequences in terms of threats was that they all were associated with socioeconomic costs. Political economy was naturalised as the obvious measure of the mentioned consequences. However, and interestingly, this naturalisation of a political economy discourse was found side by side with references to the Swedish welfare era, but the value of Swedish welfare was never questioned despite the fact that its ideological base partly deviates from the liberalization tendencies within the hegemonic political economy discourse.

\section{A context-sensitive concept}

When it came to constituting population ageing as a threat there was one significant difference between the local Västerbottens-Kuriren and the two national newspapers, and this difference was associated with the local geography. In Västerbottens-Kuriren $41 \%$ of all the articles explicitly mentioned the physical area of the inland in a way that implied that there was a difference between centre (more southern and coastal parts of Sweden) and periphery (the inland). This articulation of population ageing with a specific area was almost completely absent from the national newspapers (4\% and $5 \%$ respectively).

One similarity between Dagens Nyheter and Västerbottens-Kuriren was that "population ageing" was strongly linked to an expected shortage of labour (Table 3). However, being articulated together with "inland" in Västerbottens-Kuriren, the discussions were much more locally rooted than they were in the national newspaper, with all it meant in terms of local references and focus on municipalities rather than on the welfare state and politicians. The articulation with "inland" also meant that population ageing was constituted in a chain of meaning that equated it with signs such as "out-migration" and "unemployment". Population ageing was in these cases constituted as yet another problem that seemed to fit perfectly with the already problem-laden picture of the depopulated northern Swedish inland (cf. Eriksson 2008; 2010), and the primary reason behind population ageing was implicitly constituted as out-migration rather than declining fertility and increased longevity. Further articulations that included "long distances" and "cutbacks in services" were put forward as "facts" that made it even more problematic to age in these geographic areas. These instances also prompted old age positions such as immobility, dependency and care-dependency. The findings are interesting because they partly differ from other notions of rural ageing. Krout and Coward (1998) have emphasised how ageing in the American countryside is associated with notions of carefree smalltown dwelling, strong family support and high levels of health and satisfaction.7

There were, of course, exceptions to the negatively oriented images above. The articles that linked population ageing with the inland did in fact in some cases focus on local or regional positive trends, for example entrepreneurial success. However, even when the main points in these articles gave a positive image of the inland, the notion of "an ageing population" was always negatively charged and was seen as a possible threat. Therefore, even if somewhat differently articulated, the negatively

\footnotetext{
${ }^{6}$ Margaret Cruikshank (2003, p. 25) has also commented on how the mass media seems to unquestioningly accept the equation of population ageing with "danger to the common good".

${ }^{7}$ This idyllic view described by Krout and Coward also exists in a Swedish context (Jansson 2009). State reports hold a slightly more neutral view, albeit referring to research that suggests for example that the supposed close relations in the Swedish countryside can explain why the voluntary sector functions so well there as a compliment to (downsised) private and public services (SOU 2003:29. s. 85).
} 
charged meanings that were added to the understanding of an ageing population when the concept was articulated with "inland" enforced rather than dramatically changed the meanings that were otherwise attached to the concept.

\section{Stereotypical old age positions}

Population ageing was discussed without mentioning older people at all in $28 \%$ of the articles, and the percentage was as high as 59\% in Västerbottens-Kuriren. However, in the articles in Västerbottens-Kuriren where population ageing was articulated with "inland", there were proportionately more articles that specifically addressed the implications of population ageing for older people. The images of old age offered in these articles were similar to the ones found more generally in the material, but there were a higher proportion of them, due perhaps to the higher degree of local and geographically-specific references mentioned in the previous section. For example, $24 \%$ of the articles in Dagens Nyheter and Aftonbladet contained the old age position "taxing", while as much as 59\% of the inland-articles in Västerbottens-Kuriren mentioned this position. The same was true for the old age position "caredependent". This position was present in $12 \%$ of the national newspapers and in $31 \%$ of the articles mentioning the inland in Västerbottens-Kuriren.

Table 4: Old age positions (\%)

\begin{tabular}{|l|l|l|l|l|}
\hline & $\begin{array}{l}\text { Dagens } \\
\text { Nyheter }\end{array}$ & $\begin{array}{l}\text { Västerbottens- } \\
\text { Kuriren }\end{array}$ & Aftonbladet & Total \\
\hline None & 19 & 59 & 28 & 28 \\
\hline Taxing & 33 & 1 & 19 & 25 \\
\hline $\begin{array}{l}\text { Care- } \\
\text { dependent }\end{array}$ & 16 & 32 & 21 & 20 \\
\hline Pensioner & 14 & 0 & 11 & 11 \\
\hline Baby-boomer & 3 & 0 & 6 & 3 \\
\hline Employed & 3 & 0 & 3 & 2 \\
\hline Healthy and fit & 2 & 2 & 1 & 2 \\
\hline Other & 10 & 6 & 11 & 9 \\
\hline Total & 100 & 100 & 100 & 100 \\
\hline
\end{tabular}

When coding the material, the following definitions of the variable values were used:

Taxing: Older persons described as costly, not contributing to society, a negative burden.

Care-dependent: Older persons described as in need of care. The position as caredependent was often implicitly positioning older persons as taxing.

Pensioner: Older persons described by the word "pensioner", i.e. persons who had reached retirement age.

Baby-boomer: Older persons described as baby-boomers, i.e. persons born after World War II and now verging towards retirement. In Sweden the name used was "fyrtiotalist" (Eng.: "born in the forties").

Employed: Persons of retirement age or older, who are described as a wage-earners or portrayed in their role as employed.

Healthy and fit: Older persons described as physically healthy and active, for example taking part in social and cultural life.

In articles where older people were mentioned, the two positions that dominated were "taxing" and "care-dependent" (both positions often implied being considered "economic burdens"). These articles focused on either health care or the regional or political economy. In articles on health care the health care system was expected to experience a serious labour shortage when more and more people became old and the working population proportionally smaller. These health-related articles positioned older people as in need for health care and as economic burdens to tax payers. The following was stated in an article describing the ageing process: 
Thereafter comes a decade where the same group [older people] will become more and more care-dependent and subsequently cost more. There is no-one else to pick up the bill but the taxpayers. (DN 040624)

Articles that did not focus on health care, but still positioned older people as economic burdens, dealt primarily with the pension system. In these representations the old age position of "the pensioner" was primarily articulated together with signs such as "outside the labour market" in the sense "does not contribute" to society. This position was also associated with social costs in the sense that pensions are expected to cost more and more for society, and the related threat of pensions being lowered.

Within 25 years, the numbers of retirees will increase by 70 millions in the OECD countries, while the working population will increase by 5 millions. This will slow down growth and cause the pension system to break down. (DN 020327)

This rather negative view of older people as taxing and care-dependent also finds support in the more general research on media representations of old age (cf. Cohen 2002; Jürgens 1994; Rozanova 2006; Chappell et al 2003). With that in mind, the old age positions that were offered by the news press discourse on population ageing supported - and were supported by - a traditional and well-known strand of "negative" old age stereotypes and not the ones describing older persons as, for example, healthy and active.

However, according to discourse theory, discourses are never unequivocal (Laclau \& Mouffe 1985). Even though the representations of the ageing population primarily offered images of older people as passive and in need of care, there were some exceptions to this rule. In a few articles (3\%), which thus differ significantly from the rest of the material and from some research, older people were described as active, alert and rather healthy. These exceptions seemed to have three things in common.

Firstly, they are always in one way or another related to the view of older people as passive and in need of care. This fact supports the interpretation that even if there is a social norm stating - or even demanding - that older persons be active and healthy (Katz 2005), this norm is often articulated as a counter discourse to the discourse on older people as passive.

Secondly, the articles that portrayed older people as active often did so within a discourse on consumption. The articles that describe older people as an important and often forgotten - consumer group, focused on their good economy and the fact that the older people of today are often healthy (cf. Lövgren 2009). In these cases "youthfulness" seems to be associated with consumption, whereas "ageing" is indirectly connected to the "the failure to participate in consumer culture" (Gilleard \& Higgs 2005, p. 71). Under the headline "Trendsetters show the way", VästerbottensKuriren described how the tourist industry has discovered well-educated older people as potential consumers.

The forecast of an ageing population with plenty of money, plenty of time, and good health makes it possible for tourism entrepreneurs to shape strategies for development. (Västerbottens-Kuriren 070210)

A third point that is closely related to the previous point, is that the articles that presented old age in terms of activity were often referred to in relation to the large generation born in the 1940s. These articles portrayed the present and future pensioners (or pensioners to be) as healthy, active, affluent people that, apart from being a strong consumer group, possibly wanted to work past retiring age. This latter 
quality was, when occurring, often articulated together with the perceived future labour shortage.

Even if exceptions like those above existed in the material, they were in a minority. The comparative search where we analysed articles that discussed the expected demographic change in age structure, but that did not use the concept of population ageing, showed a much higher degree of active and healthy older persons. It was clear that the descriptions of older people as "healthy", "active", "well off" and/or "alert" occurred to a much higher degree in articles where old age positions were articulated together with, for example, "baby boomer" than when articulated with "population ageing". The otherwise common descriptions of the now retiring cohort that are found for example in magazines for older women (Lövgren 2009); that is, the baby boomers, were essentially absent from our main material. Thereby the conclusion is that old age positions in the Swedish daily news press representations of population ageing are to a much higher degree still associated with the loss and decline paradigm than are many other representations of older people in the media.

\section{Concluding discussion}

This study shows that the concept of population ageing was found primarily within the genres of "debate", "editorial" and "news" in the Swedish national and local daily press. This had an impact on the representations in many ways, for example by positioning population ageing as an urgent phenomenon. These are also genres where the authors are usually experts (at least the debate articles and editorials). Because they often refer explicitly to their sources of information (at least the news articles), it was possible to locate the positions that were present in the representations and were allowed to speak on the issue. These were: politicians, the executives of concerned organisations, and researchers.

Population ageing was primarily hegemonised by a political economy discourse. Growth and political economy were almost always either explicitly or implicitly present in the content. Most discussions took their point of departure in growth as a self-evident tool for maintaining a level of welfare or adjusting to a demographic situation that is noted for its negative consequences in relation to welfare. This corresponds with research that shows that economy-focused journalism has expanded significantly during the last decades. Mårtensson (2003) argues that the gradual political shift in Sweden towards neo-liberalism has led to an increased economisation of social functions and socio-cultural phenomena, which in turn can explain the economisation of journalism.

Regardless of whether an article represented a neoliberal or a social liberal tradition; that is, regardless of whether it was the free market or government interventions that were advocated, growth was present as the absolute and inevitable "lifesaver" in order to preserve the supposedly threatened Swedish welfare. However, the discussions were always held on a structural level. The main focus of the vast majority of the articles whose contents could be described as having their origin in a social liberal tradition held the nation state, county councils, municipalities and the pension system accountable. Thus, contrary to so-called post- or late modern tendencies where individuals are ascribed responsibility for their choices (Katz 2005; Featherstone 1995), the news press representations did not.

Therefore, growth was presented as an essential and inevitable goal; a fact that situated the discourses on population ageing and older people as burdens within a political economy discourse that revolved around budgets and cutbacks, but which 
excluded other possible aspects such as the benefits that a large proportion of older people could add to society in terms of so-called human capital (Gilleard \& Higgs 2005; cf. Lundgren 2010; Cruikshank, 2003). It was repeatedly, and at times implicitly emphasised in the studied material, how older persons do not contribute to society through paid work, thereby rendering the ways that older people may contribute in other areas invisible.

There seems to be a steady stream of evidence that the people who retire today are richer, healthier, better educated and more culturally active than before; that is, in the case of the developed world (Gilleard \& Higgs 2005). Because of the economic and problem-oriented perspective that dominates the genres of debate, editorial and news, the qualities like the ones above and those that are characteristically associated with the so-called third age and the baby boomers were not taken up because they did not pose a problem within this discourse.

This hegemonisation of population ageing within a political economy discourse produces old age subject positions that are associated with passivity and the need to be taken care of, and these positions resonate well with how old age identities have often been described (Cole 1992). Other studies (cf. Lövgren 2009; Lundgren 2010) have shown how this discourse, which is often referred to as the discourse on loss and decline, has been challenged by a discourse on older people as active, healthy and youthful. Such a challenging discourse is sometimes referred to as a norm in modern Western societies (Katz 2005), but it is a norm that coexists with its forerunner. Evidence of this exists in the fact that many of the here studied articles that portray older people as active and healthy explicitly countered the sick and/or helpless old age positions offered by the discourse on loss and decline. They thereby reproduced also these renounced positions.

As this study shows, there is no definite conclusion concerning the coverage of population ageing in the Swedish news media. The news media articulates population ageing with a multitude of different phenomena dependent on the genre and topic of the article, on the specific local context and on the range of the particular media. For example, in the articles in Västerbottens-Kuriren where population ageing was articulated with "inland", the concept came to support locally rooted notions of "outmigration" and "unemployment" at the same time as it was connected to notions of labour shortages, a threatened welfare and increased health care needs. It is possible to view the concept of population ageing in terms of a "floating signifier"; media representations use the well recognised concept of population ageing to legitimate and motivate different kinds of stories, thereby charging the concept with at times contrary meanings. ${ }^{8}$ However, the material studied suggests that the news press discourse on population ageing primarily offered the same kind of negative stereotypes of older people that gerontology tried to leave behind it. The reason for this is because of its focus on population ageing as a threat in the future. The results that Rozanova (2006), Chappell et al (2003), Elmelund-Præstekær and Wien (2006) and Nilsson (2008) arrived at were thus confirmed. They have shown how the news press is often dominated by images of older people as weak, ill, and taxing. It would be interesting to know whether scientific and other discourses on the subject of population ageing do the same.

Although firmly grounded in a political economy discourse, the news press representations of "population ageing" did not repeat the otherwise common discourse on individual choice and subsequent responsibility (cf. Katz 2005; Featherstone 1995), but placed the responsibility for dealing with the effects of

\footnotetext{
${ }^{8}$ The media is not alone in this. Research reports on "age" and "ageing" often start out with notes on population ageing just to stress the relevance of the chosen topic (Green 1993; Nilsson 2008).
} 
population ageing on the nation state, county councils, municipalities and politicians. By articulating population ageing with both political policies, political economy and older people's (as a group) reported need for care and services, population ageing was constituted as a national concern rather than a problem for the aged individual. The nation state, county councils, municipalities - and to some extent the political parties - were the main actors that were allotted responsibility for the problems that were supposed to come in the future.

The representations of population ageing were therefore problematic in a double sense. One problematic consisted of the way population ageing was unilaterally described by the news press as problematic - an obvious threat - as such. Another problematic lay in the fact that by representing population ageing as a naturalised expert concept describing a future threat to the welfare system, the blame for the expected deterioration of the welfare was ascribed supposedly inescapable demographic processes instead of political considerations.

\section{Acknowledgments}

This research is included in the Ageing and Living Conditions Programme at Umeå University and was financed by the Swedish Research Council.

\section{References}

\section{Cited news press articles}

Aftonbladet 091008. "Sjövägen" (Josefsson, L.-Å.).

Dagens Nyheter 000722. "Välkommen till jobbet i Sverige” (unsigned).

Dagens Nyheter 020327. "50+ och arbetsmarknaden" (Andersson, B).

Dagens Nyheter 020607. "Varning utfärdad" (Unsigned editorial).

Dagens Nyheter 040304. "Vi lägger om vår ekonomiska politik" (Reinfeldt, F., Odenberg, M. \& Borg, A).

Dagens Nyheter 040624."Palme spår höjda skatter" (Schuck, J).

Dagens Nyheter 061124. "Åldrande befolkning hot mot EU-ländernas finanser" (Björklund, M.).

Dagens Nyheter 070416. "Familjepolitik avgör framtidens ekonomi” (Andersson, B.).

Västerbottens-Kuriren 070210. "Trendsättare visar vägen” (Tidström, R.).

Västerbottens-Kuriren 070713. "Kan Kina lära av oss?” (Brännström, B.).

\section{Literature}

Abramsson M. (2005). Befolkningsfrågan $i$ press och politik, 1994-2004. Institutet för framtidsstudier 2005:10.

Andersson, L. (2008). Allderism. Lund: Studentlitteratur.

Andersson Odén, T. (2003). Publicistiska bokslut. Del 1: Om tidningars redaktioner och innehåll. Arbetsrapport nr. 9. Inst. för journalistik och masskommunikation, Göteborgs universitet.

Andersson Odén, T. (2005). Publicistiska bokslut. Del 2: Om tidningars redaktioner och innehåll. Arbetsrapport nr. 27. Inst. för journalistik och masskommunikation, Göteborgs universitet.

Bengtsson, T. (2010). Population ageing - a threat to the welfare state? The case of Sweden. Heidelberg: Springer-Verlag.

Berelson, B. (1952). Content analysis in communication research. New York: Free Press.

Blaakilde, A. L., Kirk, H. \& Swane, C. (1998). Mennesket i gerontologien. In A. L. Blaakilde \& C. Swane (Eds), Aldring og ældrebilleder - mennesket i gerontologien. Copenhagen: Munksgaard.

Bergh, A. (2010). Towards a new Swedish model? In T. Bengtsson (Ed), Population ageing - a threat to the welfare state? The case of Sweden. Heidelberg: Springer-Verlag.

Center for Health Communication 2004. Reinventing aging: baby boomers and civic engagement. Boston, MA: Harvard School of Public Health.

Chappell, N. et al., (2003). Aging in contemporary Canada. Toronto: Prentice Hall. 
Cohen, H.L. (2002). Developing media literacy skills to challenge television's portrayal of older women. Educational Gerontology, 28(7), 599-620.

Cohen, A.A, Adoni, H. \& Bantz, C.R. (1990). Social conflict and television news. Newbury Park. CA: Sage.

Cole, T. (1992). The journey of life: a cultural history of aging in America. Cambridge: Cambridge University Press.

Cruikshank, M. (2003). Learning to be old: gender, culture, and aging. New York and Oxford: Rowman \& Littlefield Publishers Inc.

Dail, P. (1988). Prime-time television portrayals of older adults in the context of family life. Gerontologist 28(5): 700-6.

Downe-Wamboldt, B. (1992). Content analysis: method, applications, and issues. Health Care for Women International, 13(3), 313-321.

Dozois, E. (2005). Frail gardeners and super seniors: representations of older adults in local print media. Calgary Health Region, Healthy Aging Committee.

Elmelund-Præstkær, C \& Wien, C. (2006). Ældrebilledet i medierne: En undersøgelse af dagbladenes brug af stereotyper om de ældre gennem 50 år. Nordicom Information, 1, 28, 49-58.

Eriksson, M. (2008). (Re)producing a "peripheral" region: northern Sweden in the news. Geografiska Annaler: Series B, Human Geography 90(4), pp. 369-388.

Eriksson, M. (2010). (Re)producing a periphery: popular representations of the Swedish North. Umeå: Umeå University.

Fairclough, N. (1995). Media discourse. London: Edward Arnold.

Featherstone, M. (1995). Post-bodies, aging and virtual reality. In Featherstone, M. \& Wernick, A. (Eds), Images of aging: cultural representations of later life. London \& New York: Routledge.

Fiske, J. (1991). Television culture. London: Routledge.

Gee, E.M. \& Gutman, G.M. (2000). Introduction. In Gee, E.M. \& Gutman, G.M. (Eds), The overselling of population aging: apocalyptic demography, intergenerational challenges, and social policy. Oxford: Oxford University Press.

Gilleard, C. \& Higgs, P. (2005). Contexts of ageing: class, cohort and community. Cambridge: Polity Press.

Green, B. S. (1993). Gerontology and the construction of old age. A study in discourse analysis. New York: Aldine de Gruyter.

Hall, S. (1997). Representation: cultural representations and signifying practices. London: Sage.

Harper, S. \& Leeson, G. (2008). Introducing the Journal of Population Ageing. Journal of Population Ageing $\mathrm{nr}$ 1, 1-5.

Healy, T. \& Ross, K. (2002). Growing old invisibly: older viewers talk television. Media, Culture \& Society, 24, 105-120.

Hilt, M. L. \& Lipschultz, J. H. (2005). Mass media. An aging population and the baby boomers. Mahwah: Lawrence Erlbaum Associates.

Jansson, A. (2009). Medierat centrum - marginaliserad idyll. Svenskarnas föreställning om stad och land. In Holmberg, S. \& Weibull, L. (Eds), Svensk höst. Göteborg: SOM-institutet, Göteborgs universitet. Available at http://www.som.gu.se/digitalAssets/1294/1294518_121-132.pdf

Jürgens, H. W. (1994). Untersuchungen zum Bild des älteren Menschen in den elektronischen Medien [Studies on the Portrayal of Older People in the Electronic Media]. Unabhängige Landesanstalt für das Rundfunkwesen: Kiel.

Katz, S. (2005). Cultural aging: life course, lifestyle, and senior worlds. Peterborough, Ontario: Broadview Press.

Keating, N. \& Phillips, J. (2008). A critical human ecology perspective on rural ageing. In Keating, N., (Ed.), Rural ageing. A good place to grow old? Bristol: The Policy Press.

Kessler, E.-M., Rakoczy, K. \& Staudinger, U.M. (2004). The portrayal of older people in prime time television series: the match with gerontological evidence. Ageing \& Society, 24, 531-552.

Krout, J.A. \& Coward, R.T. (1998). Aging in rural environments. In R.T. Coward \& J.A. Krout (Eds), Aging in rural settings. Life circumstances and distinctive features, 3-14. New York: Springer.

Laclau, E. (1996). Emancipation(s). London: Verso.

Laclau, E. \& Mouffe, C. (1985). Hegemony and socialist strategy: towards a radical democratic politics. London \& New York: Routledge.

Lin, M.-C., Hummert, M. L. \& Harwood, J. (2004). Representation of age identities in on-line discourse. Journal of Aging Studies, 18, 261-274.

Ljuslinder, K. (2002). På nära håll är ingen normal. Handikappdiskurser i Sveriges television 195620oo. Umeå: Umeå universitet.

Lundgren, A. S. (2010). "In the good old days": insidious nostalgia and the constitution of old age identity. Journal of Aging Studies, 24, 248-256. 
Lövgren, K. (2009). "Se lika ung ut som du känner dig”. Kulturella föreställningar om ålder och åldrande i populärpress för kvinnor over 4o. Linköpings universitet: Linköping.

Magnusson, J. (2008). Fokus ålder. Betydelserelationer och betydelseförändring i användning. Linköping: Linköpings universitet.

Magnusson, L. (2006). Håller den svenska modellen? Arbete och välfärd i en globaliserad värld. Stockholm: Norstedts.

McDaniel, S. A. (1987). Demographic aging as a guiding paradigm in Canada's welfare state. Canadian Public Policy, vol. 13, no 3, 330-336.

Mc Luhan, M. (1967). The Medium is the Message. New York: Bantam Books.

Mullan, P. (2002). The imaginary time bomb: why an ageing population is not a social problem. London: Tauris.

Mårtensson, B. (2003). Den televiserade ekonomin. Nyheter om statsbudgeten 1980-1995. Stockholm: Stockholms universitet.

Nilsson, M. (2008). Våra äldre. Om konstruktioner av äldre i offentligheten. Linköping: Linköpings universitet.

Northcott, H. C. (1994). Public perceptions of the population aging 'crisis'. Canadian Public Policy, vol 20, no 1, 66-77.

Robertson, A. (1997). Beyond apocalyptic demography: towards a moral economy of interdependence. Ageing \& Society, 17, 425-446.

Robinson, T. et al., (2003). Older adults' perceptions of offensive senior stereotypes in magazine advertisements: results of a Q-method analysis. Educational Gerontology, 29, 6, 503-519.

Rozanova, J. (2006). Newspaper portrayals of health and illness among Canadian seniors. International Journal of Aging and Later Life, 1(2), 111-139.

SOU 2003:91. Äldrepolitik för framtiden. 100 steg till trygghet och utveckling med en åldrande befolkning. Socialdepartementet. Slutbetänkande från SENIOR 2005.

Vickers, K. (2007). Aging and the media: yesterday, today, and tomorrow. Californian Journal of Health Promotion, vol 5, nr 3, 100-105.

Vincent, J. (1996). Who's afraid of an ageing population? Nationalism, the free market, and the construction of old age as an issue. Critical Social Policy, 16:3, 3-26.

Walker, A. \& Naegle, G. (1999). Introduction. In A. Walker \& G. Naegle (Eds), The politics of old age in Europe. Buckingham: Open University Press.

Winther Jørgensen, M. \& Phillips, L. (2002). Discourse analysis as theory and method. London: Sage.

www.scb.se (2009). Befolkningens medelålder efter region, kön och tid. 